\title{
Local Corpus and Praxis in Soil Management of the Manobo Tribe in Cotabato, Philippines
}

\author{
Juliet C. Bangi, Ph D ${ }^{1}$, Neyrma M. Neyra, Ph D ${ }^{2}$ and Flordeliza P. Candog ${ }^{3}$ \\ ${ }^{I}$ Associate Prof., Plant Science Dept., College of Agriculture \\ Mindanao State University-Main Campus, Marawi City, Philippines \\ ${ }^{2}$ Vice Pres. for Academic Affairs, Southern Christian College, Midsayap, Cotabato, Phils. \\ ${ }^{3}$ Dewey School International University, Battambang, Cambodia
}

\begin{abstract}
A study was conducted to document the local knowledge and practices in soil management of the Manobo tribe in Cotabato Province, Philippines. This is to determine the validity of the local corpus with the western knowledge. A total of 145 key informants were selected randomly from various Manobo groups using semi-structured survey questionnaires and field documentation. A prior informed consent (PIC) was sought by the researcher and followed by a consultation dialogue with the tribal leaders, elders and other key person of the study. Manobo tribes were located in the undulating areas of Arakan, Cotabato dominated by the sub-tribes Tinananen and Kulamanen. The Arumanen were in the distant area of Carmen and Libungan while the Obo Manobo and Kidapawanen sub-tribes were situated in Magpet and Makilala, Cotabato. About 32.41percent were tribal chieftains and farming was the prime source of living. Tribal women and children were involved in major farming activities. The farming information was obtained mostly from the tribal elders (88.97\%), chieftains (71.72\%), and co-tribesmen (54.48\%). Most of the farms were marginalized and primarily planted with upland rice, corn and root crops. Farmers practiced rotational system of gathering food, kaingin and fallow period, "tudak" or dibble method of planting, "kompak" system (communal planting), and the use of perception and actual field observation in managing the soils through the biophysical indicators. Most of the informants (88.97\%) used local corpus in farming and the 90.34 percent respondents wanted to continue the indigenous knowledge important to preserve the natural resources like water (96.95\%), soil (89.31\%), and forest trees (85.50\%). Fallow period was the known local corpus and praxis of the 78.76 percent informants including the planting of leguminous crops. The identified indigenous corpus and praxis of the Manobo were found scientifically in agreement with modern knowledge hence, considered as relevant, valid and factual.
\end{abstract}

Key words: local corpus, praxis, soil management, fallow period, intercropping

\section{INTRODUCTION}

The farming community of the rural areas around the world did understand their ecology in conservation-minded and holistic sense than would appear in the present age [1]. Traditional farming in Asia was based on sustainable cropping systems and had been replaced recently by high-yielding monoculture. It is very difficult to sustain soil fertility in cropping systems which operate at a high level of production [2]. Modern farming have developed and introduced technology for soil improvement to avert mass starvation however, it had been questioned for its ecological and economic guarantees. It is believed that studying the cultural farming practices of the farmers specifically on soil management will help in mitigating agricultural soil and rural 


\section{Www.ijsmsjournal.org}

problems. Many scientists have recognized and began to value farmers' local knowledge (corpus) and practices (praxes) which help in sustaining and maintaining our environment [3].

There are several local farming communities in the Philippines since cultural diversity abounds throughout the country. Most of the farming practices are actually based on local corpus that had been practiced from generation to generations. These praxes have been found valid, rational and suitable to the local environment where they live and the natural resources available [4], [5]. There were several studies which sought a better understanding of farmers' local knowledge and its potential users [6]. Identifying these farmers' knowledge particularly in soil management is one of the best tools in attaining a sustainable crop production that would lessen soil degradation. However, if the farmers die, the whole knowledge, worthy information and technology acquired in farming will just disappear and eventually result to the degeneration of the whole tribe.

In Mindanao, particularly in Cotabato province, is home of diverse culture and considered as the melting pot of the Tri-people : Indigenous Peoples (IPs) or the Lumads, the Moro (Muslims), and the Christian migrant settlers coming from Luzon and Visayas islands [7]. The IPs or Lumads are among the tribal groups which depend much on farming for subsistence and composed dominantly of Manobo (Menuvu) and its sub-tribes like the Kulamanon, Tinananon, Aromanon, Ilianon, Obo Manobo, Kidapawanon, and Livunganun. These sub-tribes are situated in different communities in Cotabato Province and, most of them are located in the mountainous areas. Majority of the cultural minorities still used local knowledge in farming activities including soil management practices.

Local knowledge (a.k.a indigenous knowledge) had been part of the farmers' lives as their livelihood depends almost entirely on specific skills and knowledge essential for their survival. Today, several local knowledge are at risk of becoming extinct because of rapidly changing natural environments and fast pacing economic, political, and cultural changes on a global scale. The practices may vanish as they become inappropriate for new challenges or because they adapt too slowly [8].

Considering the cultural diversity of Cotabato province, there is a need, therefore, to identify and put into written document the knowledge stored only in the minds of the local farmers particularly in soil management. It is necessary to identify these knowledge and other generated technologies that had been proven to efficiently manage the most important resources and source of life - the soil.

\section{Objectives of the study}

The general objectives of the study were to document local soil management practices of the Manobo, the dominant tribal groups in Cotabato Province and compare the validity of the local knowledge with modern knowledge with scientific facts.

Specifically, the research aimed to

1. Identify soil management practices of the Manobo tribe and generations;

2. Assess farmers ${ }^{\text {ce }}$ practices that enhance efficiently the soil quality and productivity in a specified agro-ecosystem; and

3. Validate the identified farmerse ${ }^{e e}$ generated technology as reliable tool in soil management practices. 


\section{MATERIALS AND METHODS}

\section{General procedure}

The study was conducted to document the local soil management practices of the Manobo tribe in Cotabato province. A Prior Informed Consent (PIC) certificate was secured at the inception of the study from the proper agency and authorities (i.e. NCIP, tribal leaders or chieftains, barangay officials of the IP communities) before the actual field survey (reconnaissance) to gather primary data. The approval of the proper authorities and consent of the tribal heads of the communities is important as prescribed in the PIC. It is a requirement for academic research agreement as approved in the Executive Order (EO) No. 247 Sect. $2 \& 3$ and the guidelines stipulated in the Intellectual Property Rights (IPR) law. The said executive order is a prescribed guidelines and procedures for bio- prospecting, genetic resourcing and other related by-products and derivatives for scientific and other purposes. An assessment or validation study followed after the recording of the different local knowledge in soil management for scientific basis or comparison.

\section{Location and Duration of the Study}

The study was conducted in the Manobo community situated in the different municipalities of Cotabato province, Philippines to document local soil management and identifies innovative technology in soil conservation measures from July 2011 to 2013 . The study duration was extended due to location instability particularly in the selected study sites in the Cotabato Province, Philippines.

\section{Selection of Key Informants}

The Manobo tribe was selected based from the criteria adopted from Low-External Input Agriculture (LEIA) Newsletter 6 (1990) that include (a) long history of farming, (b) existence of indigenous peoples (IPs) and other tri-people willingness to share indigenous knowledge, (c) accessibility of the area, (d) good peace and order situation, (e) integrity of the culture, and (f) socio- economic profile of the area. A semistructured questionnaire was used by the researchers to obtain a brief demographic profile of the randomly selected key informants. The number of respondents was determined using Slovin formula. The participation of the informants were encouraged through focal discussion to appreciate and preserve the cultural identity and integrity of the tribe in the locality.

\section{Description of the study sites}

Reconnaissance was conducted in the tribal communities after the approval of PIC to record the farming practices of the local people, the dominant bio-physical endowments, geographic characteristics (topography, soil type, etc.), land use and other factors of soil management. Study area descriptions were taken through simple transect mapping. Other locale descriptions were obtained from secondary data sources, published literature, formal and informal reports of the government and non-government agencies in the province, municipality and national level.

\section{Documentation and Description of Local Soil Management Practices}

The descriptions of local soil management were taken during interview from the key informants and those directly involved in different farming practices. There were two aspects considered in the documentation of local soil management: 
1. Local cognitive systems (corpus - knowledge) - this refers to the historical and ecological context of land use or soil utilization, crops/plants growing, and the changes made through time including its economic value; and

2. Local management system (praxis - management practices)_ - this refers to the background of soil management practices, technology innovation made by certain tribes and/or share the proven technology to other local farmers; discontinuous practice as judge by the users, non-users and observers.

\section{Assessment and Validation of Local Knowledge in Soil Management Practices}

1. Transect Mapping - necessary to determine the factors affecting soil classification and land use structure.

2. Field observation and soil analysis - through biotic indicators, visual method, and laboratory analysis specifically in the soil fertility improvement and soil erosion control.

Tabulated primary data were analysed using descriptive statistics (i.e. frequency and percentage).

\section{RESULTS AND DISCUSSION}

\section{Brief Description of the Study Sites}

Manobo tribal communities are usually located in the remote barangays and undulating areas of Arakan, Pres. Roxas, Magpet, Makilala, Libungan, Carmen, and Matalam municipalities of Cotabato Province. They often inhabited the secluded and mountainous areas and lived together as one tribe and family. Table 1 and Figure 1 shows the municipalities and respective barangays in Cotabato province considered as study areas including the number of respondents or key informants.

Arakan is a second class municipality of the 2nd district of Cotabato province with 28 barangays. Manobo is the official language and reported to have the highest population growth rates of 4.99 percent, higher than the provincial growth rate (2.34\%) in 2000 (http://www.cotabatoprov.gov.ph).

It has the most number of Manobo tribal communities or barangays as 70 percent are situated in the undulating to mountainous (steep) areas with an elevation of about 200 meters above sea level (masl).

Due to massive logging in the early 1970s, the early Manobo were forced to settle in areas away from the migrants. At present, the place is the territory of a number of ethno-linguistic groups predominantly the Manobo Kulamanon and Tinananon tribes including other ethnic groups like Teduray and Matigsalug of Bukidnon (http://www.arakan-cotabatoprov.gov.ph/index.php?catl=2\&cat2).

Pres. Roxas is originally part of Kidapawan and formerly called as Barrio Kabacan. It has 25 barangays and belongs to the 2nd district of the province. It is bounded by Arakan on the north, Magpet on the eastern side, Matalam on the western part and Kidapawan in the southern portion with an elevation of 140 masl. Most of the barangays in the northern part are dominated by Manobo tribe.

Carmen was named by the early Manobo tribe as "kalalaw" (jar of water) and later as "Landing" or referring to Landing Field Reservation. Carmen was named later in honor of the Chief Cadastral Survey Party in 1924 (del Carmen). There are 28 barangays in the municipality and about 10 barangays are predominantly inhabited by Aromanon Manobo. The place has an elevation of about 40 masl and bounded on the north by Bukidnon province, on the east by Pres. Roxas and Kabacan municipalities, southern part by Maguindanao province and western part by Aleosan municipalities. 
Table 1.

Municipalities and barangays dominated by Manobo tribe in Cotabato province selected as study areas and the corresponding number of key informants.

\begin{tabular}{|ccl|}
\hline Municipality & $\begin{array}{c}\text { No. of Key } \\
\text { Informants }\end{array}$ & \multicolumn{1}{c|}{ Barangays } \\
\hline Arakan & 67 & $\begin{array}{l}\text { Datu Ladayon, Datu Mantangkil, Libertad, Ganatan, Lanao Kuran } \\
\text { Tumanding, Sinayawan, Katindu, San Miguel, Kinawayan, Kabalantian, } \\
\text { Maria Caridad, Salasang, Sumalili, Kulaman Valley, Valencia Binoongan } \\
\text { Guinto, Datu Inda, Lamalama, Bato-Bato Datu Sundungan, Salat, } \\
\text { Pres. Roxas }\end{array}$ \\
Kamahuring Sarayan \\
Makilala & 20 & $\begin{array}{l}\text { Pangao-an, Tagbac, Manobo, Manobisa, Datu Celo } \\
\text { Buenavida, Malasila, Kisante }\end{array}$ \\
Carmen & 10 & Aroman, Bentangan, Kibudtungan, Kimadzil, Liliongan, Cadiis \\
Libungan & 12 & Sinapangan, Barongis, Malengen, Grebona, Kitubod, Montay \\
\hline
\end{tabular}

1st

District of

Cotabato

Province

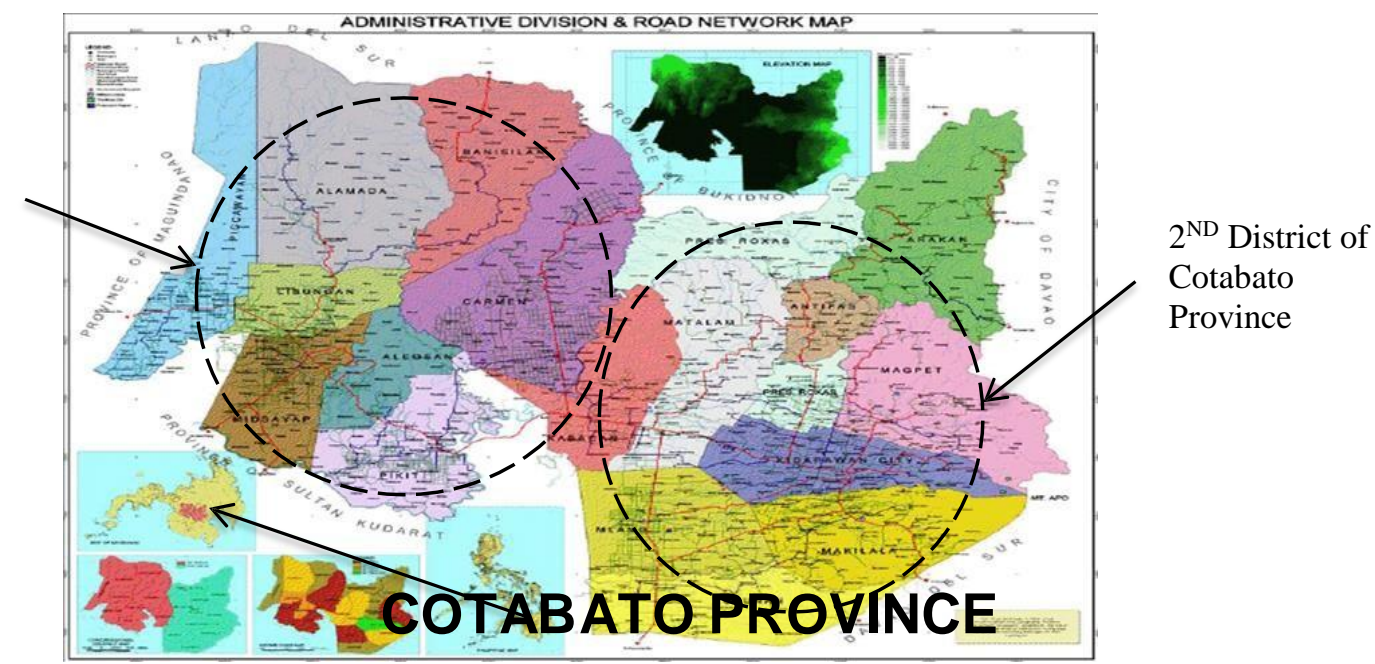

Figure 1. Geographical location of Cotabato Province showing the 1st and the 2nd district municipalities and respective barangays where the Manobo communities are situated (photo adapted from the website of Cot. province 2012).

Magpet is a first class municipality with 32 barangays. It has an elevation of 300 masl. It is bounded in the eastern part by the foothill of Mt. Apo (the highest mountain in the country), in the southern part by Kidapawan city, in the northern part by Arakan with sloping and mountainous terrain. Manobo is the official language of the tribal villages and inhabited predominantly by Obo Manobo.

Makilala is a first class municipality with 38 barangays with sloping elevations (mountainous) of 240 masl. The place was formerly called barangay "Lamitan" and later became "Makila" which stands for the three biggest barangay, "Malasila, Kisante, and Lamitan". Manobo tribal communities in Makilala are located near the foothill of Mt. Apo. Most of them came from Obo Manobo, Kidapawanen, and Davao Manobo groups. 
Libungan is a second class municipality with 20 barangays situated in the Northwestern part of the province with Libungan River as the main boundary from the Municipalities of Alamada, Banisilan and Carmen. Historically, Libungan had different names given by ancient Manobo settlers, "dadas" meaning road down by the river.

\section{Brief Demographic Profile of the Manobo Respondents}

The key informants were mostly male 71.72 percent and about 96 percent of the total respondents were pure-blooded Manobo while 4 prcent were Manobo - Bagobo mixed blood. Among the subtribes, Tinananon Manobo had the highest number of informants (40.69\%) and Aromanen was 25.52 percent. The least number of tribe informant was Livunganen (0.69\%) (Fig. 2). About 50 percent of the informants were members of the respective ethnic tribes and 32.41 percent were tribal leaders (chieftains or datu). There were informants acted as "sitio" leaders (6.21\%), pastors or church leader of Christian congregations (6.21\%), "purok" presidents (4.83\%), and "timuay" (Arumanen's spiritual leader) with $0.69 \%$ (Fig. 3).

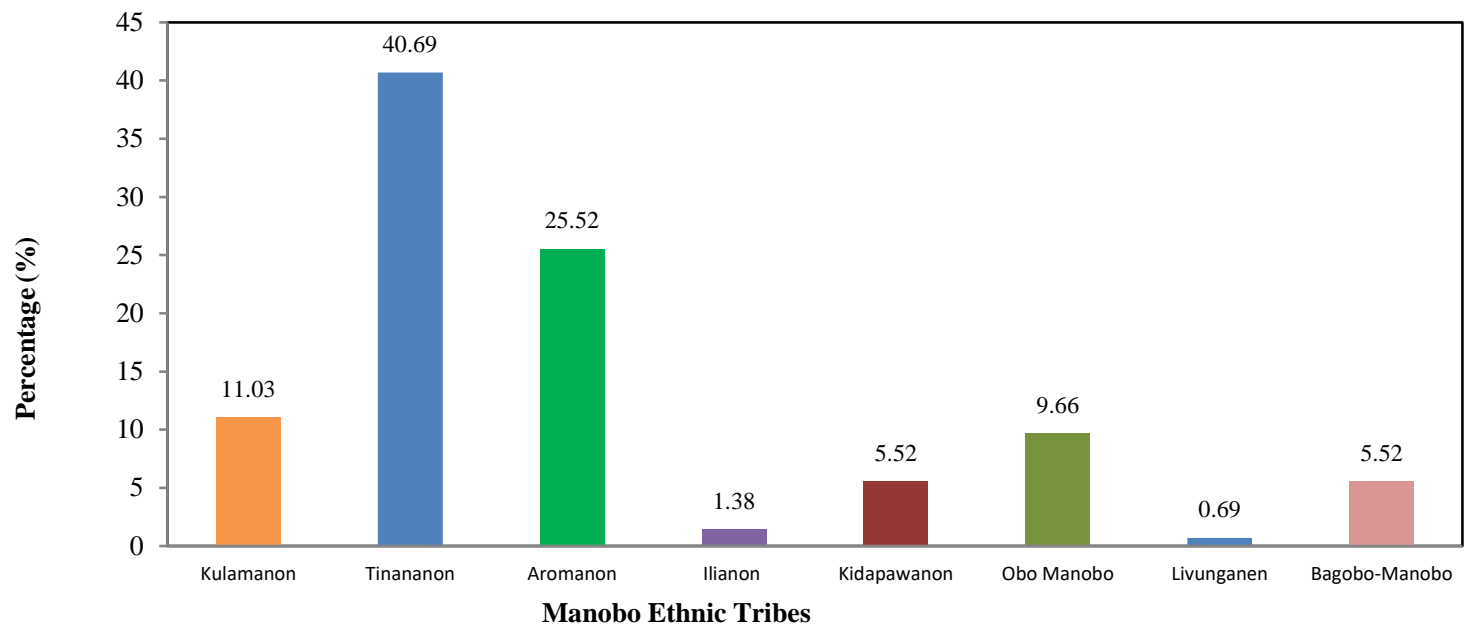

Figure 2. Key informants' (respondents) ethnic tribal group affiliation in the Ethnopedology study conducted in Cotabato province. 


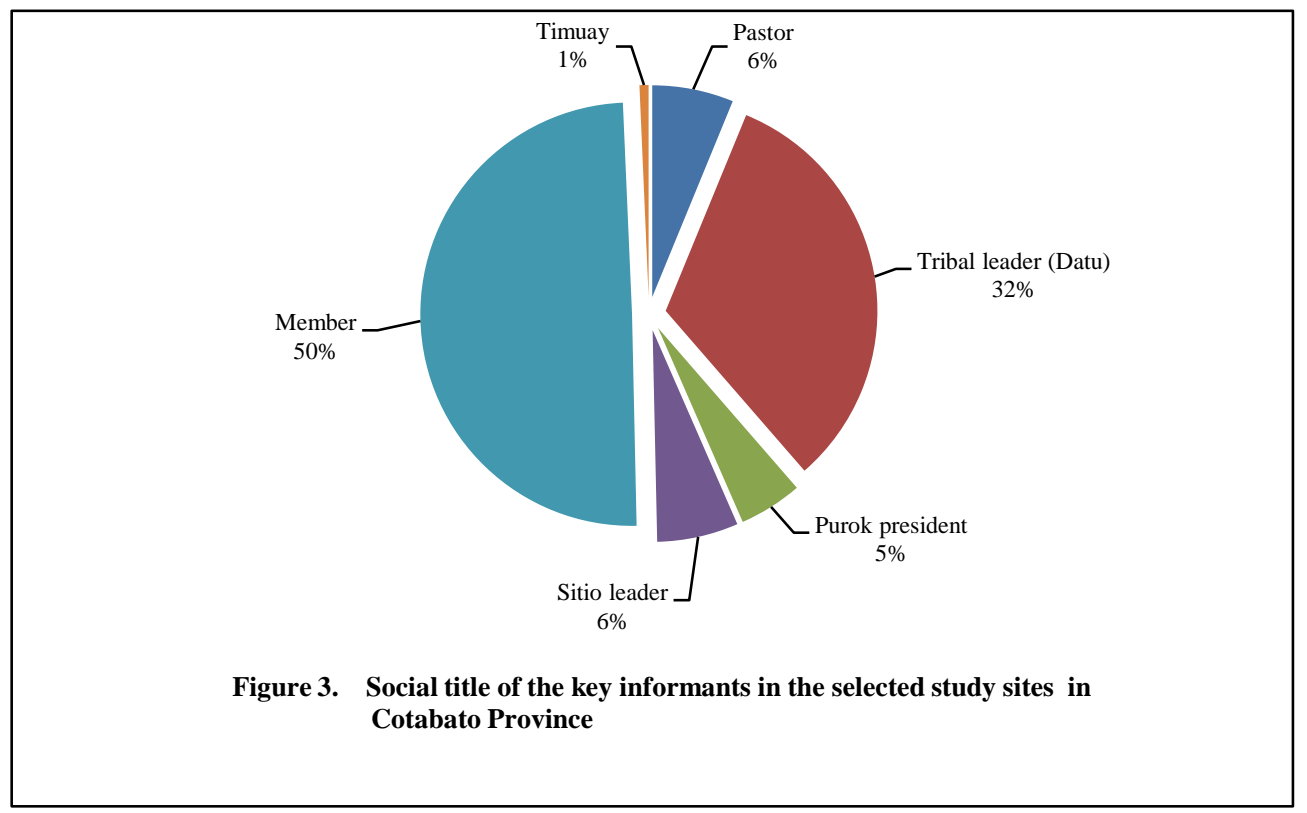

\section{Manobo tribe Local knowledge and practices in soil management}

For several decades, the Manobo tribe (including sub-tribes) experienced lush vegetation, forested mountains and clear rivers and lakes teeming with fishes and wildlife. Key informants could differentiate the primeval food production areas from the present denuded mountains, murky rivers and lakes and limited food sources. The early Manobo were wanderers (nomads), they do not farm. However, when logging concessionaire came in and the population of migrant settlers increased, food became inadequate. They settled in one village and began to plant crops and domesticate animals. Manobo tribes are known to practice "slash and burn method" (or kaingin) or swidden agriculture in planting upland rice, root crops, corn, vegetables and other commodity.

A sample transect walk diagram of Tinananen farm in Tumanding, Arakan, Cotabato is shown in Figure 4 that provides a detailed farm features, description of available resources, land use, community problems and opportunities. The rolling topography is planted with local variety of corn and upland rice while the lower elevation has root crops (cassava and taro root). The soil is dark-colored, clay-loam textured and farmers do not apply fertilizer but practiced intercropping of field beans and other vegetables as cash crops. Accordingly, they found peanut suited in a reddish-brown colored soil and have lower yield if planted in dark-colored soil.

In Table 2 shows the soil management practices of Manobo tribe according to ethnic groups and generations. Based on historical accounts, in the early period of 1920 s to 1940s, most of the tribes used indigenous knowledge. They were dependent on the available resources within the forests which provided the tribes with basic needs including recreational opportunities. The tribes transferred from place to place to gather food and when food sources became inadequate, they deserted the area and allowed the plants to regrow and recover for a period of time. They practiced "kaingin" system and fallow period and burned weeds, shrubs, and logs before planting as part of the land preparation. When the soil became unproductive for 2 croppings, the area left uncultivated for two or three cropping season to restore back the fertility of the field.

Zero and/or minimum tillage operation is another soil management used by the tribal farmers. They used "tudak" system or dibble and/or stick method in sowing cereal seeds specifically in rolling and steep areas. The method of planting used will reduce soil erosion in elevated areas during heavy rainfall. They practiced 
“kompak" (Kul. \& Tin., "gawang" Ar.) system, a tribal soil management to reserve a common area for planting various crops, similar with multiple cropping as required by the tribal leaders. The tribal members (by family) are compelled to participate in planting various crops aside from the respective family-owned farms. This system of collective planting connotes a value of "bayanihan" (communal unity) among the tribes which will ensure continuous food supply or production within the community. The planting of various crops conserve the soil from torrential rains, and add up organic matter from the diverse crops grown.

The communal planting of the Manobo tribe usually starts early part of March or April and not on May as it would affect land preparation causing massive soil erosion. The month of May is the onset of rainy season in the Cotabato Province (with Type III climate). Root crops like gabi (taro), aroids (bisol), yam (ube) cassava, sweet potato (camote) are commonly planted in the kumpak system as the secondary staple food of the Manobo tribe.
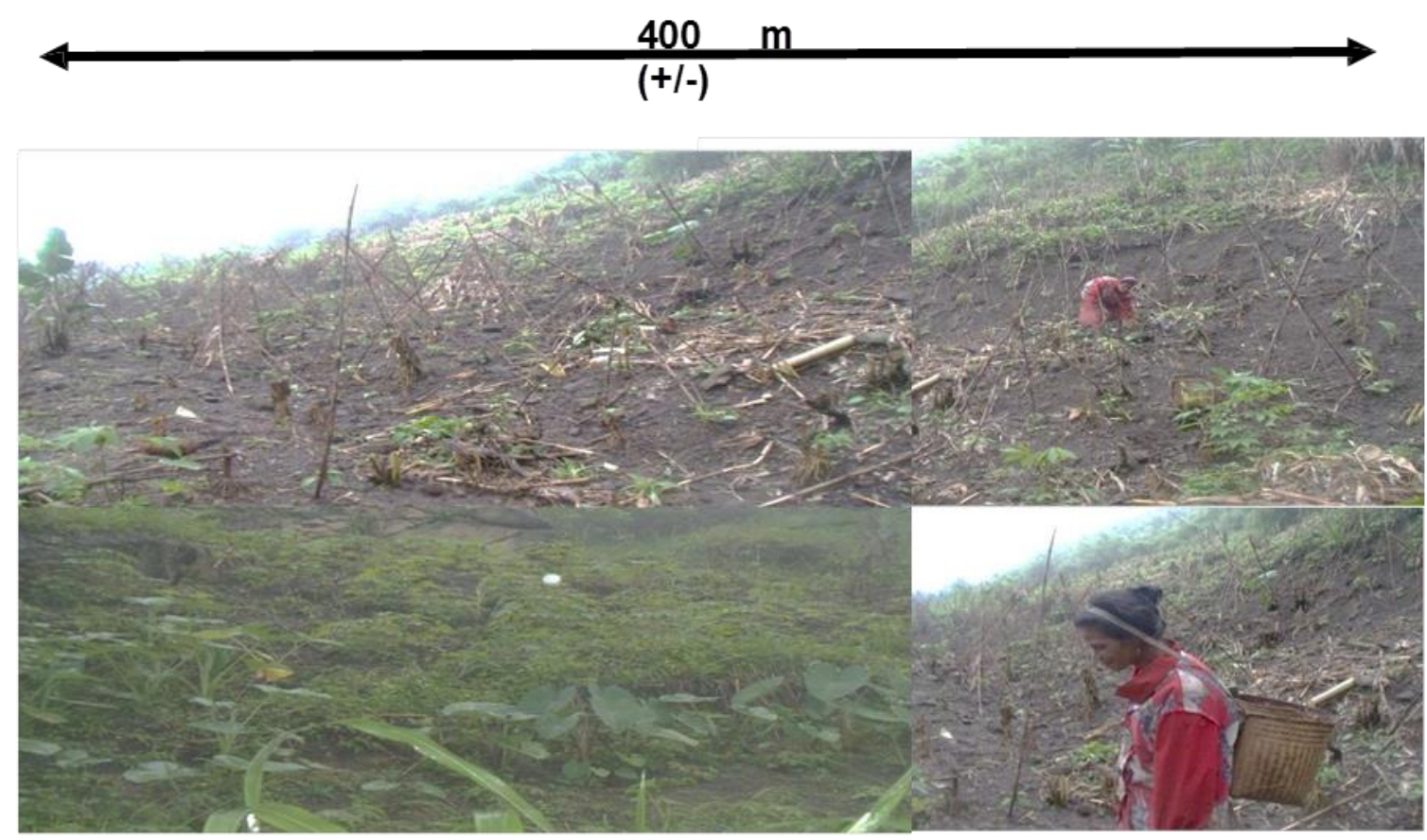

Figure 4. Transect walk diagram of the selected farmland of the Manobo Tinananen tribe in Tumanding, Arakan, Cotabato Province, Philippines. 


\section{Table 2 .}

Local soil management practices (praxes) of the Manobo tribe according to ethnic groups (sub-groups) and by generations in the selected study sites of Cotabato Province, Philippines $(n=145)$ *

Generations (vrs) Tinananen

Kulamanen

Arumanen

Obo \& Kidapawanen Manobo ethnic groups

$1920 \mathrm{~s}-1940 \mathrm{~s} * *$

Manobo tribe did not employ soil management practices in this era since forests were still intact (no resource inflow and outflow). Forests were pristine and Manobo tribe lived within the bounds of nature. Most of the Manobo practiced nomadic existence (hunting and gathering of food from different forests and/or places). Practiced slash-and-burn (kaingin) and fallow period as method of farming.

Tribal community practiced "kompak" system of food production (common production area maintained by the whole community)

Practiced "panubadtubad" (traditional farming ritual).

$1950 \mathrm{~s}-1960 \mathrm{~s}$

1970s-1980s practiced slash-and-burn method of farming and fallow period.

practiced "kompak" system of food production - practiced "panubadtubad" (traditional farming ritual). Some practiced nomadic existence practiced slash-and-burn method of farming and fallow period . , practiced "kompak" system of food production practiced (panubadtubad" (traditional farming ritual). still practiced nomadic existence practiced slash-and-burn method of farming and fallow period.

practiced "kompak"

system of food production

practiced panubadtubad' (traditional farming ritual).

Some Manobo still practiced gathering of food from the forests and other pristine places.
Practiced slash-and-burn method of farming and fallow period. Other tribesmen gathered food in deep forests. .practiced "kompak" system of food production

In the early 1960s to early 1970s, there was massive forest clearing or logging in the whole province of Cotabato Province. Many Manobo were displaced and fled to mountainous areas leaving their fields for food production Other Manobo tribesmen worked in the logging operation for survival and existence of the family (adapted from Lydia M. de Leon).

$\begin{array}{ll}\text { Practiced slash-and-bum } & \text { Practiced slash-and-bur } \\ \text { method of farming and fallow } & \text { method of farming and }\end{array}$ period.

- practiced "panubadtubad" (traditional farming ritual). , use inorganic fertilizers and hybrid corn seeds fallow period.

- Used chemicals (fertilizers and pesticides) for crop production (i.e. rice and corn). practiced slash-and-burn method of farming and fallow period.

Used chemicals (fertilizers and pesticides) for crop production (i.e. rice and corn). practiced slash-and-burn - method of farming and fallow period .

- Other tribesmen practiced farming ritual. some community practiced "kompak" system of food

\begin{tabular}{|c|c|c|c|c|}
\hline & $\begin{array}{l}\text { planting steep or rolling } \\
\text { topography } \\
\text { \ome community practiced } \\
\text { “kompak” system of food } \\
\text { production }\end{array}$ & $\begin{array}{l}\text { “kompak" system of food } \\
\text { production } \\
\text { Seldom practiced panubad- tubad } \\
\text { Practiced “tuda } k \text { " system }\end{array}$ & $\begin{array}{l}\text { tubad" } \\
\text { Some community practiced } \\
\text { "kompak" system of food } \\
\text { production } \\
\rrbracket \text { Practiced “tudak" system }\end{array}$ & practiced "tudak" system \\
\hline 1990s -2000 & 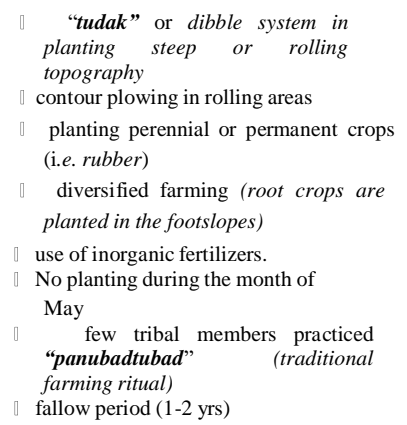 & $\begin{array}{l}\text { "tudak" or dibble system in } \\
\text { planting steep or rolling } \\
\text { topography } \\
\text { diversified farming (multiple } \\
\text { cropping) } \\
\rrbracket \text { plant permanent crops } \\
\text { (usually rubber) } \\
\rrbracket \text { mulching (weed) } \\
\rrbracket \text { use inorganic (chemical) } \\
\text { fertilizers } \\
\rrbracket \text { contour plowing } \\
\rrbracket \text { fallow period (1-2 yrs) } \\
\text { No planting during the month } \\
\text { of May }\end{array}$ & $\begin{array}{l}\text { “tudak" or dibble system in } \\
\text { planting steep or rolling } \\
\text { topography } \\
\begin{array}{l}\text { Relay cropping or staggard } \\
\text { planting }\end{array} \\
\text { practiced "panubadtubad" } \\
\text { (traditional farming ritual) } \\
\text { fallow period (1-2 yrs) } \\
\square \text { use of inorganic fertilizers } \\
\text { contour plowing } \\
\text { practiced diversified farming }\end{array}$ & $\begin{array}{l}\text { "tudak" or dibble system in } \\
\text { planting steep or rolling } \\
\text { topography } \\
\Downarrow \text { use of inorganic fertilizers } \\
\text { contour plowing } \\
\text { plant perennial or permanent crops } \\
\text { (like rubber and fruit trees) } \\
\text { practiced diversified } \\
\text { farming }\end{array}$ \\
\hline $2000 \&$ present & $\begin{array}{l}\text { contour plowing in rolling } \\
\text { topography } \\
\text { diversified farming and planting } \\
\text { permanent crops (i.e.rubber) } \\
\text { use of inorganic and organic } \\
\text { fertilizers. } \\
\text { maintain mini-forests and other } \\
\text { trees/shrubs/bamboos in gullies and } \\
\text { creeks } \\
\Downarrow \text { cover cropping (rubber -based area) } \\
\| \text { No planting on the month of May }\end{array}$ & $\begin{array}{l}\text { diversified farming or multipl cropping } \\
\text { with permanent crop } \\
\rrbracket \text { cover cropping (rubber-based) } \\
\rrbracket \text { use inorganic (chemical) } \\
\text { and organic fertilizers } \\
\rrbracket \text { contour plowing in rolling areas } \\
\square \text { No planting on the month of May } \\
\text { maintain mini-forests and other } \\
\text { trees/shrubs/bamboos in } \\
\text { gullies and creeks }\end{array}$ & $\begin{array}{l}\| \text { maintain mini-forests and other trees } \\
\text { /shrubs or bamboos in gullies anc } \\
\text { creeks } \\
\text { Relay cropping or staggard } \\
\text { planting } \\
\rrbracket \text { use of inorganic fertilizers } \\
\| \text { contour plowing } \\
\rrbracket \text { plant permanent trees or crops } \\
\text { like rubber, coconut etc. } \\
\rrbracket \text { practiced cover cropping } \\
\text { (rubber areas) }\end{array}$ & 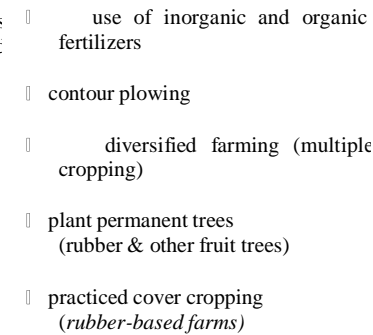 \\
\hline
\end{tabular}

"Based on actual interview using questionnaire and observation in the community. 
Soil management of the older generation were based on perception and/or actual field observation coupled with its belief in the deity of "manama" or "magbabaya" (unseen being and considered as gods). They offered traditional ritual or prayer called "panubad-tubad" and made use of their senses in the management aspect through observable biophysical factors in the environment including the growth and yield of the plants. The early Manobo can determine a productive field based from biotic indicators, like existing plants and animals (biota) which also define the non-biotic aspect of the farm (soil, water, and climate).

Leaving the area for 1- 2 years (fallow) is the most known local practice of the Manobo for soil fertility management as cited by 78.76 percent respondents (Table 3). There were farmers that left the farmed area and allow the regrowth of cut trees as mentioned by the 39.82 percent respondents. Other local knowledge employed relay cropping $(9.73 \%)$ and not to plant during May (3.54\%), the start of rainy season (Table 3). Heavy rains will cause massive soil erosion and form gullies and landslide in the undulating places. Other local practices (praxes) of the Manobo farmers include the planting of leguminous crops (intercropping or crop rotation) by the 69.03 percent respondents, planting of permanent crops (like rubber, coffee, cacao, coconut and other fruit bearing trees) by the 40.71 percent farmers, and use of organic fertilizers (animal manure) in their farming practices by the 38.94 percent respondents.

The biophysical assessment of the Manobo tribe on soil fertility evaluation using local knowledge is shown in Table 3. The assessment made were based on the perception and observed physical properties of soil, biotic factors, visual symptoms of crops and actual yield. According to the farmers, soil color is one of the common physical indicators that determine the fertility of the soil. Fertile soils are dark colored (tabunok, Bis.) with pulverized or granular structure (buhaghag, Bis.) as identified by the 80.69 and 55.86 percent informants, respectively. Besides, a fertile soil is not sticky or clay textured (demileg Ar.) according to the 64.14 percent respondents. The observation of the local tribe relates to the findings of several soil scientists that the dark-colored soil is high with organic matter. Biotic factors were also used by the Manobo tribe as soil fertility indicators. The 55.17 percent mentioned that fertile soil have the presence of earthworms (liwate, Ar., Tin. \& Kul.), while the 42.76 percent farmers said that fertile soil have many weeds (ilamunen, Ar.) growing specifically broadleaves. The 28.97 percent Manobo farmers observed the presence of termites (tendo-tendo, Ar., tandotando Kul. \& Tin.) and black ants (makot, Ar., lummotik, Tin. \& Kul.) in the soil.

Other respondents considered growing trees like “Lauan" to be an indicator of soil fertility as mentioned by the 40 percent respondents, “Anonang” tree (38.62\%), “badiang” (aroids) by 29.66 percent, “bolo" bamboo, and "bonowang” trees including “boyo-boyo" 6.90 percent. Visual symptoms of plants (color) and actual crop yield are also indicators of soil fertility according to the $26.90 \%$ and $37.93 \%$ respondents, respectively (Table 3). The low soil fertility indicators used by the Manobo farmers were the presence of loose stone (sandy) (13.10\%), red soil (23.45\%) and clayey soil (demileg, Ar., batoan no livota, Kul. \& Tin.) $(15.86 \%)$, other biotic indicators include shrubs $(37.93 \%)$, cogon weeds $(50.34 \%)$, hard wood trees like “anatong”, “wayan”, and “katangan- tangan” plants (6.90\%) (Table 3). Majority of the Manobo farmers $(77.93 \%)$ would like to continue using indigenous knowledge in soil management and only $22.03 \%$ contradict the adoption of IK (Table 3$)$.

Other local knowledge employed were staggard planting $(9.73 \%)$ and planting of leguminous crops (intercropping or crop rotation) by the $69.03 \%$ respondents, planting of permanent crops (like rubber, coffee, cacao, coconut and other fruit bearing trees) by the $40.71 \%$ informants, and use of organic fertilizers (animal manure) in their farming practices by the $38.94 \%$ respondents. The practice on fallow period or leaving the farmed area for 1-2 years were done when crop yield started to decrease. This is an indigenous praxis proven to restore back the fertility of the soil. The Manobo farmers practiced slash-and-burn method (kaingin) thus newly opened farms have high soil fertility level. After 3-4 cropping period, the fertility of the soil declined and Manobo farmers have to transfer and open new field for crop production. 


\section{Table 3.}

Soil fertility evaluation and management practices using local knowledge of the Manobo tribe (key informants) in the selected study sites of Cotabato Province, Philippines $(\mathrm{N}=145)$.

\begin{tabular}{llccccc}
\hline $\begin{array}{l}\text { Soil fertility evaluation using } \\
\text { Indigenous knowledge system }\end{array}$ & Arakan & $\begin{array}{c}\text { Pres. } \\
\text { Roxas }\end{array}$ & Carmen & $\begin{array}{c}\text { Magpet } \\
\&\end{array}$ & Libungan & Total \\
& & & & Makilala & &
\end{tabular}

\section{MUNICIPALITIES}

\section{Biophvsical assessment for Fertile soil}

a) Physical prop. (visual/feel method)

- black color (tabunok)

10

- pulverized soil (granular)

- not sticky soil or clayey (demileg)

3

8

\section{3}

- presence of earthworms (liwate)

- presence of black ants (makot),

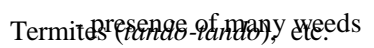

3

- presence of bolo (bamboo)

- presence of lauan tree (big trees)

- presence of badjang

- presence of anonang tree

- presence of bonowang, "boyo-boyo"

c) Visual symptoms of crops

- Leaf color of crop grown (green

d) Actual production

\section{$\underline{\text { Low / Poor soil fertility indicators }}$}

$$
\begin{aligned}
& \text { a) Physical properties } \\
& \text { - loose stone / sandy } \\
& \text { - red color soil } \\
& \text { - clayey soil (demileg) }
\end{aligned}
$$

\section{b) Biotic indicators}

- presence of Almasiga tree

- presence of short trees (shrubs)

- presence of cogon weeds

- presence of worst hard weeds

(wayan, katungon-tungon \& anatong)

- poor growth of crops and seed germ.

\section{Makilala}

$\%$


Soil management practices $\underline{\text { (praxes) }}$

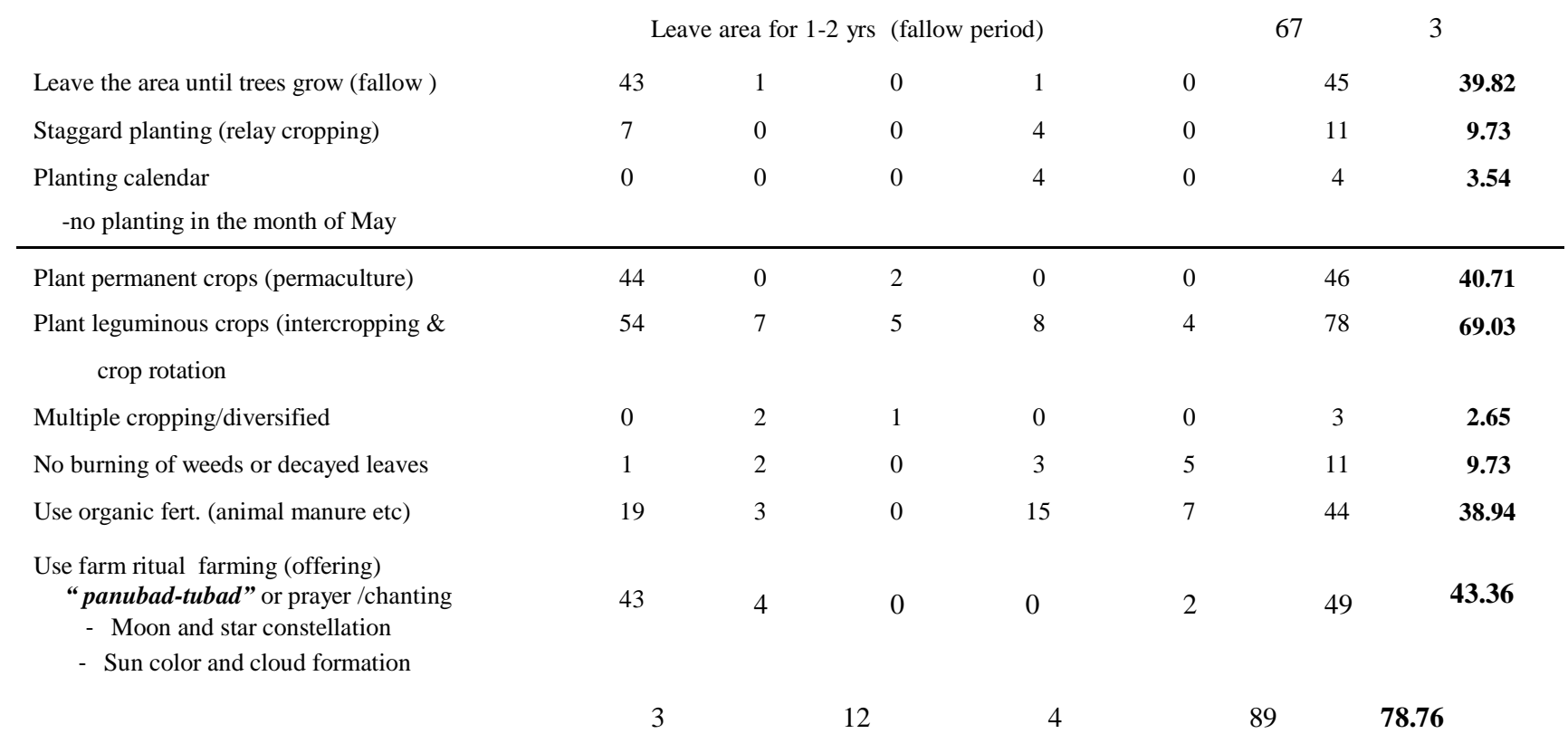

In Table 4 shows the comparison and validation of Manobo indigenous knowledge (corpus) and practices (praxis) in soil management with the modern and scientific method. It shows that most of the knowledge and practices of the Manobo tribe have scientific explanation and therefore found relevant, valid and realistic. The knowledge and practices are product of the systematic analysis and actual observation of the local farmers in the field for decades. Several authors attested the traditional knowledge and practices of the local people were all scientifically valid and statistically testable [9], [10], [11], and other argues that local knowledge had been proven over centuries and must be recognized [12].

Manobo tribes are rich in indigenous knowledge and practices however, it is alarming to note that only few of the tribal elder taught the younger generation to keep the applicable corpus and praxis which are very important in upholding the cultural identity of the Manobo tribe and for sustainable food production. There were 43.76\% Manobo informants that have strong inclination with local beliefs or perception (cosmovision) and execute thanksgiving ritual as part of the soil management. The identified indigenous corpus and praxis of the Manobo tribe were compared and validated with modern knowledge. It shows that almost of the traditional IK of the informants have similarities and in agreement with scientific approaches hence, considered as relevant, valid and factual and not a mere superstitious belief of the informants. The indigenous knowledge of the Manobo became outmoded and gradually replaced with new technology from the migrants as a result of environmental alterations, farm landscape changes, the crops planted, farm management practices and the possessed cultural values. The use of green manure and compost of the farmers in San Andres, Cuba [13] were similar to the Manobo tribes' practice of using compost This findings were similar to the ethnopedological observation of other ethnic tribes in Africa, Asia and America [14]. 
Table 4.

Comparison, validation and explanation of Manobo tribe indigenous knowledge (corpus) and practices (praxis) in soil management with scientific method

\begin{tabular}{|c|c|c|}
\hline $\begin{array}{c}\text { Farming Practices \& } \\
\text { Soil Management }\end{array}$ & Local corpus and praxis & Modern / Western /Scientific validation \\
\hline $\begin{array}{l}\text { Soil classification for } \\
\text { planting crops (i.e. } \\
\text { peanut, root crops) }\end{array}$ & $\begin{array}{l}\text { dark-colored soil (tabunok) good for planting } \\
\text { root crops and cereals (upland rice and corn) } \\
\text { as based from tribal elder experience. } \\
\text { - red-colored soil is very suited to peanut, mungbear } \\
\text { and other legumes. According to Manobo farmers } \\
\text { they found out peanut produced more number of } \\
\text { pods and bigger in size. }\end{array}$ & $\begin{array}{l}\text { dark-colored soil are rich in organic matter } \\
\text { (OM) and usually have lower chroma and value } \\
\text { using the Munsell soil color notation (ex. } \\
2.5 \mathrm{YR} 3 / 3 \text { dark reddish brown), good soil } \\
\text { structure, high water holding capacity and well } \\
\text { aerated. } \\
\text { - Dark-red soil (2.5YR } 3 / 6 \text { ) are highly weathered } \\
\text { with low nutrient level and acidic. Peanut and } \\
\text { other legumes are able to fix } \\
\text { nitrogen through the N-fixing bacteria at the } \\
\text { nodes of the root system (Rhizobia). Mycorrhizae } \\
\text { micro- organisms also form a mutualistic } \\
\text { relationship with the roots and } \\
\text { helps in the efficient absorption of water, } \\
\text { phosphorus and other minerals needed by } \\
\text { plants. }\end{array}$ \\
\hline $\begin{array}{l}\text { "Kaingin" and fallow } \\
\text { period }\end{array}$ & $\begin{array}{l}\text { - Higher yield or production in the newly } \\
\text { opened area and decreases in the nex } 1 \\
\text { cropping season (up to } 3 \text { croppings only). } \\
\text { - Farmers leave the farmed (kaingin) area and transfel } \\
\text { to another place to allow the field to rest for } 1-3 \\
\text { croppings (fallow). }\end{array}$ & $\begin{array}{l}\text { - A newly opened (forested) area has high } \\
\text { organic matter (OM) accumulated in the soil surface } \\
\text { from the litters of plants or fallen } \\
\text { leaves of trees. The product of decomposition } \\
\text { includes humic acid that affect the pH of the soil. } \\
\text { The ashes from burned twigs, logs, weeds, } \\
\text { and other trashes act as liming material that corrects } \\
\text { the pH of the soil including the humic acid from } \\
\mathrm{OM} \text { decomposition. Ash contains calcium } \\
\text { carbonate, a liming agent that deacidify the soil to } \\
\text { increase its pH. "Kaingin" area lost its nutrients by } \\
\text { plant absorption and erosion thus, need to recover } \\
\text { naturally through crop-free period (fallow). }\end{array}$ \\
\hline
\end{tabular}

No planting on the
month of May
preparation and planting before or earlier than May
(based from experience for generation to generation).
Accordingly, if the tribe will prepare and plant
ate or near the month of May, there is a tendency c
l have lower yield or failure of production.
$\mathrm{t}$

\begin{tabular}{l}
\hline Diversified \\
"communal" \\
$\begin{array}{l}\text { "copping/farming } \\
\text { protection } \\
\text { management) }\end{array}$
\end{tabular}

- "Kompak" or "gawang" is a system of communal farming among Manobo tribe, c traditional planting of various crops (diverse plants, in a common area as identified by the elders or chieftains. This was practiced by the people before to have a common food source in the community aside from the family- owned cultivated field. This is to ensure for a productive environment. Legumes are intercropped with rice and corn and the bigges plants (like banana papaya etc) were planted along the sides of the farm as barrier.

- Root crops are usually planted in the midslopes and footslopes of rolling areas.
- Based from the Climate map of the Philippines modified corona classification, the Manobo community in the different municipalities of the Cotabato Province has a Type III climate. The month of November to April is partly dry and wet for the rest of the year.

- There will be heavy rains that leads to intense soil erosion or landslide during the month of May that will result to low yield or failure o crop production.

- Diversified planting of crops is akin to multiple cropping. It secure the food sources of the people by increasing the number of crops per area and reducing the risks of crop failure due to pest and diseases problem. The more diverse the crops the less it be infested with insect pests and disease. Besides, it secures the soil since leguminous plants are intercropped with non-legumes and covers the soil from intense rainfall in higher elevation. Some plants act as soil barrier when planted in the contour lines thereby reducing soil erosion. Besides, the more number of crops planted will contribute to the addition of organic matter in the soil.

Manobo offers agricultural products to the deity of their believed god ("manama") as thanksgiving to the harvest and keeping the fields safe. 
- The ritual of the Manobo is a sign of positive outlook of the cultural values to be grateful always to the resources within the community. This develops self-esteem of the people or the community to take care of the environment as it is the source of their existence.

\section{CONCLUSION AND RECOMMENDATION}

The identified indigenous corpus and praxis of the Manobo tribe were compared and validated with modern or western knowledge. It shows that almost of the local knowledge of the key informants have similarities and in agreement with scientific approaches hence, considered as relevant, valid and factual and not a mere superstitious belief of the informants. The local knowledge of the Manobo became outmoded and gradually replaced with new technology from the migrants as a result of environmental alterations, farm landscape changes, the crops planted, farm management practices and the possessed cultural values.

The only problem with the Manobo tribe was the massive intrusion of the migrant settlers in the tribal communities and the rapid conversion of ancestral domain into high-valued plantation crops which may cause the total displacement of indigenous people in the Cotabato province. The government should and must protect the rights of the Manobo and safeguard their tribal communities from the selfish or vested interest of migrants, businessman, politicians and other private entities. It is evident that most of the tribal elders and chieftains (datu and bai) wanted the younger generations to use the applicable local corpus and praxis in the present farming scenario. This is an opportunity to inculcate the rich Manobo local knowledge and enable them to appreciate and rebuild their self-esteem in the uniqueness of the culture and traditions. The local government unit and NGOs in the study area will help in the implementation of the sustainable agriculture principles to persuade the younger generations to change its views on local knowledge as mere superstitious belief, baseless and unscientific.

The only problem with the Manobo tribe was the massive intrusion of the migrant settlers in the tribal communities and the rapid conversion of ancestral domain into high-valued plantation crops which may cause the total displacement of indigenous people in the Cotabato province. The government should and must protect the rights of the Manobo and safeguard their tribal communities from the selfish or vested interest of migrants, businessman, politicians and other private entities.

\section{REFERENCES}

[1] Mumm Von Mallinckrodt, F. 1997. Sustainable Agriculture and Human Development. Principal Technical Adviser, UNDP. In Sustainable Agriculture and Rural Development. Paper presented at an International Symposium on Sustainable Agriculture and Rural Development (ISSARD, 1993. Beijing). Ed. In-Chief; Prof. Mei Fangquan and Dr. F. K. Bishay. 1997. China Agricultural Science Tech. Press. People's Republic of China. Pp 13-19.

[2] Arihara, J. 2000. Cropping Systems and Their Mechanisms of Nutrient Uptake, Food and Fertilizer Tech. Center (FFTC) Extension Bulletin 491. Oct. 2000 pp 1-18.

[3] Briggs, J. I., D. Pulford M. Badri \& A.S. Shaheen. 1998. Indigenous and Scientific Knowledge : The Choice and Management of Cultivation Site of Bedonin in Upper Egypt. Soil Use and Management 14-246.

[4] Sillitoe, P. 1998. Knowing the Land: Soil and Land Resource Evaluation and Indigenous Knowledge. Soil Use and Management 14: 188-193.

[5] Warren, D. M. 1991 "Using Indigenous Knowledge in Agricultural Development"; World Bank Discussion Paper No.127. Washington, D.C.: The World Bank.

[6] Warren, D.M., L.J. Slikkerveer \& D. Brokensha (Eds) (1995) "The cultural dimension of development: Indigenous knowledge systems". London: Intermediate Technology Publications

[7] Alternative Forum For Research In Mindanao (AFRIM). 1999. MINDANAO 21 - A Mindanao People's Agenda for Peace, Equity and Sustainable Development. Davao City, Philippines. pp 1-30 
[8] Warren, D. M. 1992. "Using Indigenous Knowledge for Agriculture and Rural Development." A Concept Paper for Exploring the Potential Utility of The Global Network of Indigenous Knowledge Resource Centers for International and National Agricultural Research Centers. Ames, Iowa: CIKARD, Iowa State University.

[9] Warren, D. M. 1989. "Linking Scientific and Indigenous Agricultural Systems." pp. 153170, In J. L. Compton, (ed.), The Transformation of International Agricultural Research and Development. Boulder: Lynne Rienner Publishers.

[10] Ettema, Christien H. 1994. Indigenous soil classifications: what is their structure and function, and how they compare to scientific soil classifications? University of Georgia, Athens GA, USA. 1-13 pp

[11] Bellon, M.R. and J.E. Taylor. 1993. "Folk" soil taxonomy and the partial adoption of new seed varieties. Economic Development and Cultural Change 41 (4):762-786

[12] Thrupp, L.A. 1989. Legitimizing local knowledge: form displacement to empowerment for the Third World People. Agriculture and Human Values 6(3): 13-24

[13] Lisa Kissing I, A. PimentelII y María ValidoII. 2009. Participatory Soil Improvement: A Cuban Case Study

In Fertility Management. Cultivos Tropicales (Cultrop) v.30 n.2 La Habana abr.-jun. 2009. versión impresa ISSN 0258-5936

[14] Barrera-Bassols N. \& $\boldsymbol{J}$. A. Zinck. 2003. Ethnopedology: a worldwide view on the soil knowledge of local people. ${ }^{a}$ Departamento de Ecología Vegetal, Instituto de Ecología A.C., km 2.5 Antigua Carretera a Coatepec,

91000, Jalapa, Veracruz, Mexico ${ }^{\mathrm{b}}$ Soil Science Division, International Institute for Geoinformation Science

and Earth Observation (ITC), PO Box 6, 7500AA, Enschede, The Netherlands

Available online 7 November 2002. 


\section{DATA GATHERING PROCEDURE}
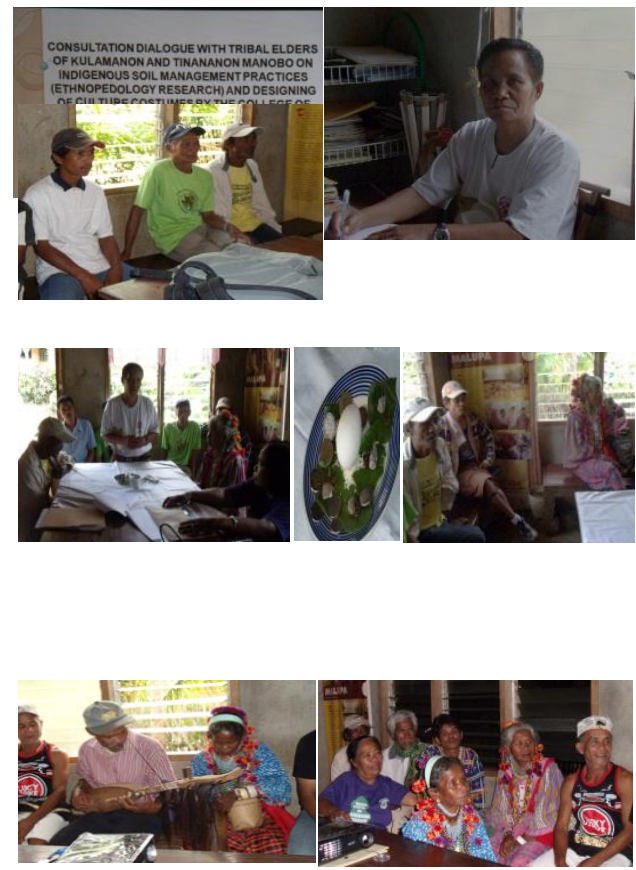

Consultation dialogue with the Manobo elders and chieftains (datu and bai) followed by a panubadtubad (indigenous prayer ritual) held in MALUPA Office, Arakan, Cotabato before the conduct of the ethnopedology study (June 2011).

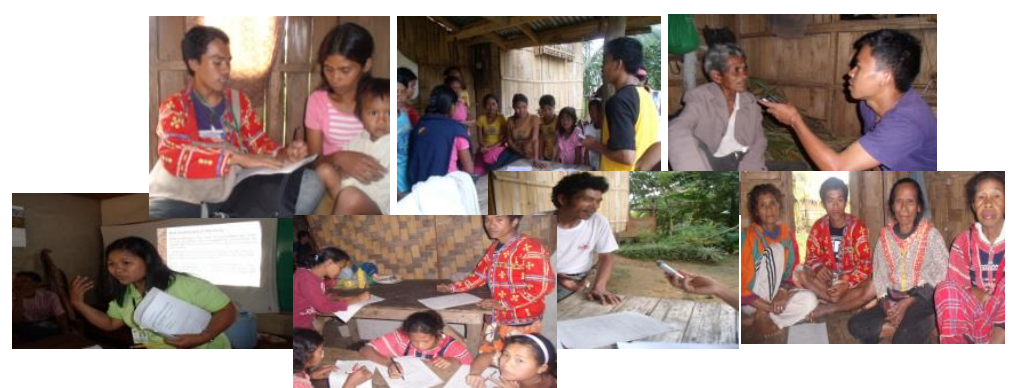

The key informants during the actual survey and interview of the Tinananon Manobo tribe with the enumerator and interpreter (student assistant).

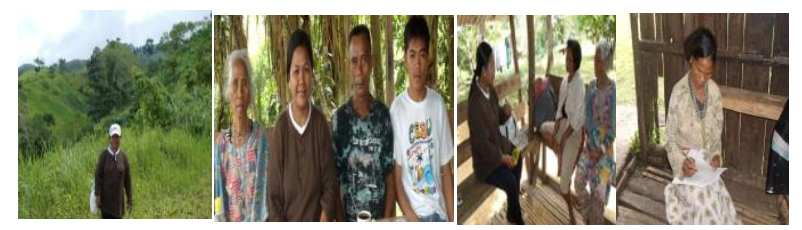

The research leader (JCBangi) with Kulamanen tribal elders (bai and datu) and together with interpreter (Ilianen tribe) as key informants during the demographic survey and reconnaisance in Kabalantian, Arakan, Cotabato.

\section{MANOBO TRIBE INDIGENOUS KNOWLEDGE (IK) BASES IN SOIL FERTILITY ASSESSMENT}

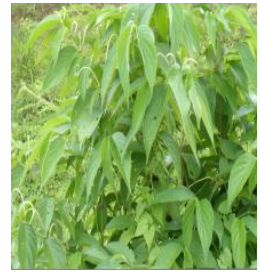

Plant growing (ex.Boyo-boyo)

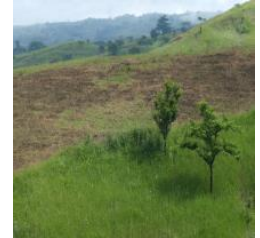

Cogonal area

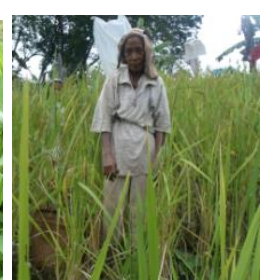

Crop stand and yield

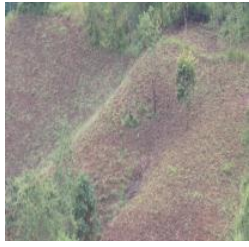

No trees / plants Meso \& micro

(bare soil) fauna
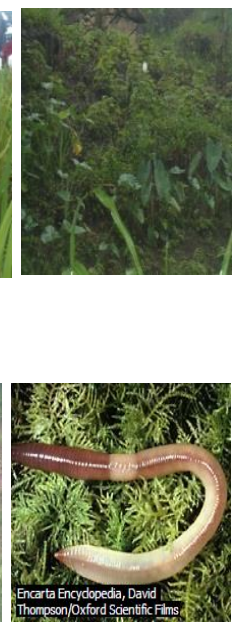

Biotic indicators

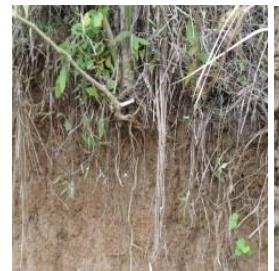

Soil color

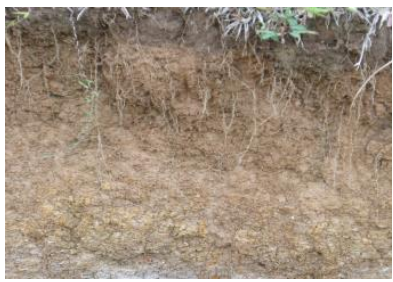

Non-biotic indicators

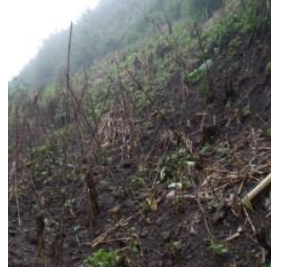

Topography

Compact and shallow soil 